\title{
SECOND TEACHERS' TRAINING WORKSHOP: FEEDBACK OF THE PARTICIPANT FACULTY MEMBERS
}

\author{
Rano Mal Piryani , ${ }^{1}$ Suneel Piryani, ${ }^{2}$ Narayan Gautam ${ }^{3}$
}

\section{ABSTRACT}

\section{INTRODUCTION}

Teachers training is amongst the faculty development programs that facilitates in acquiring, and updating educational skills, thereby improving teaching learning practices. Universal College of Medical Sciences (UCMS) Bhairahawa, Nepal organized second teachers training workshop in September 8-13, 2019. The objective of this study was to seek the immediate reaction of the participant faculty members and assess it.

\section{MATERIAL AND METHODS}

The valid semi-structured questionnaire was used for taking feedback of the participants. The questionnaire was composed of four parts: A) demographic information, B) overall feedback on training workshop, C) feedback on specific group of sessions and D) Feedback regarding strengths, area for improvement, immediate impact and application in practice. Data was analyzed using SPSS version 21.

\section{RESULTS}

The participants rated training on scale 1-10 (1=poor, $10=$ excellent) regarding its usefulness ( $7.88 \pm 1.58)$, content $(7.44 \pm 1.55)$,

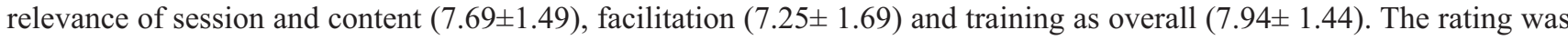
notable. The rating on Likert scale 1-4 (1= not important, 4= extremely important) for "sessions on curriculum" (3.38 \pm 0.50$)$, "sessions on teaching/learning methods" (3.25 \pm 0.68$)$, "sessions on PBL" (3.06 \pm 0.68$)$, "sessions on microteaching" (3.56 \pm 0.51$)$ and sessions on assessment (3.19 \pm 0.75$)$ was also remarkable. All participants strongly agreed (4.00 \pm 0.0$)$, training has transformed them as better educator. The participants shared adequate content delivered systematically, group work exercises were best resources, and resource persons were friendly and competent, and suggested to reduce time of training and include more group work. Almost all participants except one perceived training has enormous impact on them academically, professionally and personally and all committed what's learnt/acquired will apply in practice.

\section{CONCLUSION}

Overall, reaction of the participants was constructive and they acknowledged the importance of training and agreed training has transformed them as better educators. Almost all participants perceived training has immense impact on them academically and they committed what's learnt will apply in practice.

\section{KEYWORDS}

Feedback, Faculty development program, perception, reaction, Teachers' training workshop

1. Department of Internal Medicine, Universal College of Medical Sciences, Bhairahawa, Nepal.

2. Department of Community Health Sciences, Aga Khan University Karachi Pakistan.

3. Department of Biochemistry, Universal College of Medical Sciences, Bhairahawa, Nepal

DOI: https://doi.org/10.3126/jucms.v9i02.42022 


\section{INTRODUCTION}

Strengthening the capacity of faculty members in basic academic domains is vital to transform the teaching learning environment and educational performance of learners. ${ }^{1-5}$ Teaching is one of the professional competencies of health professions, so, health professional teachers must learn, acquire and embrace it. Teachers' training is amongst the faculty development programs that facilitates in acquiring, imparting and updating educational skills, thereby cultivating seeds of best teaching learning practices. ${ }^{6-9}$ After successful organization of first Teachers training workshop', Health Professions Training Committee (HPTC) of Universal College of Medical Sciences (UCMS), Bhairahawa, Nepal organized second Teachers' Training Workshop during September 8-13,2019. The objective of this six-days Teachers Training Workshop was to enhance the capacity of faculty members in their role as educators focusing on teaching, learning and assessment of the students. The objective of this study was to seek the immediate reaction of participant faculty members and assess it.

\section{MATERIAL AND METHODS}

Universal College of Medical Sciences (UCMS), Bhairahawa, Nepal established in 1998 affiliated to Tribhuvan University, Institute of Medicine (TU, IOM), Kathmandu, Nepal have been running undergraduate courses in Medicine, Dentistry, Nursing, and Pharmacy and Postgraduate courses in Medicine, and Dentistry. After successful organization of first Teachers' training workshop during March 11-16, 2019, UCMS organized second Teachers' training workshop during September 8-13, 2019. It was of six days duration.

Principal author as a chief coordinator of Health Professions Training Committee (HPTC) UCMC conducted the second Teachers' training workshop as a principal resource person. Thirteen resource persons/facilitators conducted sessions on different subjects of health professions education. Sixteen participants participated in training workshop; 5 each were from clinical sciences, and basic sciences departments and 3 each from dental sciences, and nursing sciences departments.

The curriculum of Teachers' training workshop was comprised of five groups of sessions: Group-I sessions on curriculum, Group -II sessions on teaching/learning, Group-III sessions on problem-based learning (PBL), Group -IV sessions on microteaching, and Group- $\mathrm{V}$ sessions on assessment.

Group-I sessions on curriculum: Role of faculty and faculty development program, teaching communication skills, feedback skills, essence of curriculum and syllabus, introduction to behavioral objectives and group work on writing behavioral objectives, community based/ community oriented medical education-modern concepts and approaches, ethics for medical educator and role of Teacher.

Group-II sessions teaching/learning: Overview of teaching/learning methods, small group dynamics and small group discussion, role play, principles of adult learning, interactive teaching/ learning methods, teaching clinical skills, role of standardized patients and skill lab in clinical skills teaching with group work on script writing for standardized patient.

Group-III sessions on PBL: Overview of PBL in health professions education, criteria for selection of problem for PBL session with mock PBL session, developing scenario of problem for PBL with group work, preparation of tutor guide for developed scenario with group work and small group tutorial for PBL.

Group-IV sessions on Microteaching: Introduction to microteaching, lesson plan for microteaching, use of audiovisual aids, preparation of lesson plan and presentation by individual participant for microteaching, microteaching practice by the participants, video recording and video review with reflection of individual participant and observation of peer and supervisor (assessor).

Group-IV sessions on assessment: Basics of assessment with group work on blueprinting for assessment, assessment of knowledge and understanding with group work developing multiple choice questions (MCQs), Assessing clinical skills and attitude-I with group work on objective structured clinical examination/ objective structured practical examination (OSCE/OSPE), assessing clinical skills and attitude II-shortcase, long-case and viva voce and other methods of assessment including performance based assessment (PBA) and workplace based assessment (WPBA).

At the end of Teachers' training workshop, feedback of the participants was taken on the valid semi-structured questionnaire. The questionnaire was composed of four parts.

Part A. Demographic information: Information were sought on age in years, sex, year of graduation and post-graduation, teaching experience of teaching undergraduate and post graduate and received medical education related training before.

Part B. Overall feedback on training workshop: This part had two close ended questions. One was on rating training on scale 1-10 (1=poor, 10=excellent) for usefulness, content, relevance, facilitation and training as overall. Another question was whether training transformed you as a better educator rated on Likert Scale 1-4 (4=strongly agree, 3=fairly agree, $2=$ slightly agree, $1=$ not agree) . 
Part C. Feedback on specific group of sessions: This part contained five closed ended questions. All five questions: sessions on curriculum, sessions on teaching/learning methods, sessions on PBL, sessions on microteaching and sessions on assessment rated on Likert scale 1-4 (4=extremely important, 3=moderately important, $2=$ slightly important, $1=$ not important).

Part D. Feedback regarding strengths, area for improve ment, immediate impact and application in practice: This part had four open ended questions. One was on good-points/ strengths of training, second on areas for improvement and third on overall immediate impact of training workshop and fourth on what's learnt apply in practice.

The informed consent was taken from the participants and ethical approval was obtained from Institutional Review Committee of UCMS. The collected data was checked for completeness, accuracy and consistency and entered in IBMS SPSS version 21 for analysis. Descriptive analysis was done. The frequency, mean and standard deviation were computed.

\section{RESULTS}

The findings of the present study are presented under four headings.

\section{Part A. Demographic information}

The age of participants was $33.94 \pm 2.98$ years (range 29-40 years); $10(62.5 \%)$ were males and $6(37.5)$ females. The teaching experience was $44.12 \pm 34.76$ months (range 10 months to 144 months) for teaching undergraduate students and $26.0 \pm 26.47$ years (range 0 months to 96 months) for teaching postgraduates. Their year of graduation were between 2000-2014 and of post-graduation between 2007 2018. Only one participant received medical education related training before.

\section{Part B. Overall feedback on training workshop}

The participants rated the second Teachers' Training Workshop on scale 1-10 (1=poor, $10=$ excellent); the rating was notable (Table 1).

Table 1. Rating of the participants on Teachers' training workshop

\begin{tabular}{lc}
\hline \multicolumn{1}{c}{ Item } & Rating (Mean \pm SD) \\
\hline Usefulness (scale 1-10) & $7.88 \pm 1.58$ \\
Content (scale 1-10) & $7.44 \pm 1.55$ \\
Relevance of session and content (scale 1-10) & $7.69 \pm 1.49$ \\
Facilitation (scale 1-10) & $7.25 \pm 1.69$ \\
Overall (scale 1-10) & $7.94 \pm 1.44$ \\
\hline
\end{tabular}

Participants' response on "Will this training transform you a better educator?" was significant $4.00 \pm 0.00$ rated on Likert scale 1-4 (4=strongly agree, $3=$ fairly agree, $2=$ slightly agree, $1=$ not agree)
Part C. Feedback on specific group of sessions

The rating of the participants on specific group of sessions conducted in Teachers' training workshop" was also remarkable.

Table 2. Rating of the participants on specific group of sessions conducted in Teachers' training workshop

\begin{tabular}{lc}
\hline \multicolumn{1}{c}{ Item } & Rating (Mean \pm SD) \\
\hline $\begin{array}{l}\text { Sessions on curriculum conducted in training rated } \\
\text { on Likert scale 1-4 }\end{array}$ & $3.38 \pm 0.50$ \\
$\begin{array}{l}\text { Sessions on teaching/learning methods conducted } \\
\text { in training rated on Likert scale 1-4 }\end{array}$ & $3.25 \pm 0.68$ \\
$\begin{array}{l}\text { Sessions on PBL conducted in training rated on } \\
\text { Likert scale 1-4 }\end{array}$ & $3.06 \pm 0.68$ \\
$\begin{array}{l}\text { Sessions on microteaching conducted in training } \\
\text { rated on Likert scale 1-4 }\end{array}$ & $3.56 \pm 0.51$ \\
$\begin{array}{l}\text { Sessions on assessment conducted in training } \\
\text { rated on Likert scale 1-4 }\end{array}$ & $3.19 \pm 0.75$ \\
\hline
\end{tabular}

(4=extremely important, $3=$ =moderately important, $2=$ slightly important, 1=not important)

Part D. Feedback regarding strengths, area for improve ment, immediate impact and application in practice.

Table 3. Good points/strengths of Teachers' training workshop

\begin{tabular}{lc}
\hline \multicolumn{1}{c}{ Strength / Good points } & No of participants \\
\hline Content of sessions was adequate, appropriate and realistic & 6 \\
Participants became enthusiastic, confident and motivated & 5 \\
Content delivered in a systemic and scientific way & 4 \\
Group work exercises and other interactive tasks were true resources & 4 \\
Active and participatory involvement & 4 \\
Resource person and facilitator were supportive, friendly, competent & 4 \\
and caring & \\
Started on time and finished on time, good time management & 3 \\
Microteaching sessions and video demonstration of recorded & 3 \\
presentations of microteaching & \\
Update on new methods of teaching learning and assessment & 3 \\
Enhanced skills for teaching learning & 2 \\
Conducive and friendly environment for learning & 2 \\
Systemic organization of workshop & 1 \\
Better utilization of audiovisual aids & 1 \\
Helpful volunteers & 1 \\
Evaluation by chief coordinator of training & 1 \\
Refreshments & 1 \\
\hline
\end{tabular}

Table 4. Areas for improvement

\begin{tabular}{lc}
\hline \multicolumn{1}{c}{ Strength / Good points } & No of participants \\
\hline Reduce time & 3 \\
Include more group work and little bit more time for group work & 3 \\
No side talk by resource persons & 2 \\
Topics should focus how to make a good teacher, topics like conflict & 2 \\
and community based medical education may be omitted & \\
Improvement in arrangement at venue (e.g. noises of fans were & 2 \\
distracting) & \\
Lessen group work & 1 \\
Invite other resource person & 1 \\
Improve teaching methods & 1 \\
Make more interesting & 1 \\
\hline
\end{tabular}


Table 5. Overall immediate impact of training workshop

\begin{tabular}{|c|c|}
\hline Participant No & Statement \\
\hline 1 & "Learnt a lot" \\
\hline 2 & "Good and applicable to my career" \\
\hline 3 & $\begin{array}{l}\text { "Enhances my communication skills and thinking abilities by } \\
\text { brainstorming" }\end{array}$ \\
\hline 4 & "Helps to improve my way of teaching and assessment of students" \\
\hline 5 & $\begin{array}{l}\text { "I updated with newer methods of teaching and learning and realized the } \\
\text { way I was teaching students is traditional and outdated" }\end{array}$ \\
\hline 6 & $\begin{array}{l}\text { "It has positive impact, created positive vibe, motivated me to practice } \\
\text { what is learnt and made me realize my weak points" }\end{array}$ \\
\hline 7 & $\begin{array}{l}\text { "It has improved my attitude and gives me good confidence while } \\
\text { teaching" }\end{array}$ \\
\hline 8 & $\begin{array}{l}\text { "It certainly improves my teaching skills and helps me in creating } \\
\text { healthy class room environment" }\end{array}$ \\
\hline 9 & $\begin{array}{l}\text { "It definitely Improves my presentation skills, teaching skills and } \\
\text { assessment skills and reforms professionally" }\end{array}$ \\
\hline 10 & "I am motivated myself to be good teacher" during this training" \\
\hline 11 & $\begin{array}{l}\text { "I am motivated and encouraged to use some of the methods learnt to } \\
\text { improve learning of my students" }\end{array}$ \\
\hline 12 & "It improves my teaching and learning methods" \\
\hline 13 & "Not something for myself to work upon" \\
\hline 14 & "Training improves my teaching skills" \\
\hline 15 & "I leant teachers should be student centered, I adopt it" \\
\hline 16 & "I acquire skills to teach students in a better manner" \\
\hline
\end{tabular}

Table 6. What's learnt apply in practice

\begin{tabular}{|c|c|}
\hline Participant & Statement \\
\hline 1 & $\begin{array}{l}\text { To become good teacher by knowledge, skills and professional ethics. } \\
\text { Follow the principles in our daily life. }\end{array}$ \\
\hline 2 & $\begin{array}{l}\text { Update teaching learning methods. } \\
\text { Manage how to be a good teacher. }\end{array}$ \\
\hline 3 & $\begin{array}{l}\text { Introduce more active learning for students. } \\
\text { Do better use of audio visual aids. }\end{array}$ \\
\hline 4 & $\begin{array}{l}\text { Improve communication skills, especially how to break bad news. } \\
\text { Improve way to assess. } \\
\text { Try to become good teacher. }\end{array}$ \\
\hline 5 & $\begin{array}{l}\text { Use appropriate teaching learning methods. } \\
\text { Use scientific way for assessing the students. } \\
\text { Use MCQs, SAQs, LEQs for assessment. }\end{array}$ \\
\hline 6 & $\begin{array}{l}\text { Apply what is learnt in regular lectures, clinical rounds, and assessment of } \\
\text { students. }\end{array}$ \\
\hline 7 & $\begin{array}{l}\text { Develop better power point presentation. } \\
\text { Organize content relevance to the topic. }\end{array}$ \\
\hline 8 & Apply teaching skills learnt in workshop in my teaching \\
\hline 9 & $\begin{array}{l}\text { Apply what is learnt in teaching learning of students, evaluating students and } \\
\text { professional development }\end{array}$ \\
\hline 10 & I should apply lesson planning and assessment methods. \\
\hline 11 & $\begin{array}{l}\text { I do planning to use new ideas and techniques to enhance learning of my } \\
\text { students }\end{array}$ \\
\hline 12 & transform my teaching "How to make the students understand concept \\
\hline 13 & I instill curiosity in students \\
\hline 14 & $\begin{array}{l}\text { I have to be more interactive with students, arouse interest in students and } \\
\text { more systematic in teaching. } \\
\text { I change the methods of assessment. }\end{array}$ \\
\hline 15 & I focus more upon "How to teach besides what to teach" \\
\hline 16 & I have to become more interactive to engage my students \\
\hline
\end{tabular}

\section{DISCUSSION}

Teachers training program nurture the teaching and assessing competence and capacity of faculty members of health professions education. ${ }^{3}$ The objective of this study was to seek immediate reaction of the participant faculty members and assess it as immediate feedback supports in what went well and what are the areas for improvement.
The rating of participant faculty members regarding usefulness of training workshop, content, relevance of session and content, facilitation and training as overall was notable on scale $1-10$ (1=poor, $10=$ excellent $)$. All the participant faculty members strongly agreed that this training has transformed them as better educator. The rating on "sessions on curriculum", "sessions on teaching/learning methods", "sessions on PBL", "sessions on microteaching" and "sessions on assessment" was also remarkable on Likert scale 1-4 (4=extremely important, 3=moderately important, $2=$ slightly important, $1=$ not important).

The some of the main strengths of workshop shared by the participants are: content of sessions was adequate, appropriate and realistic, participants were enthusiastic, confident and motivated, the content was delivered in a systemic and scientific way, group work exercises and other interactive tasks were true resources, active and participatory involvement of participants, and resource person and facilitator were supportive, friendly, competent and caring. Reduce time and include more group work and little bit more time for group work were among the key suggestions given by the participants.

The participant faculty members of teachers training workshops conducted at B.P. Koirala Institute of Health Sciences, Nepal stated that training was educational, they learnt teaching learning methods, assessment technique and became better skilled in teaching abilities reported by Baral et al in their study. ${ }^{9}$ The study done by Joshi M et al disclosed that faculty development workshop conducted at Patan Academy of Health Sciences Nepal effectively improved faculty's knowledge, its application in the areas of adult learning and providing feedback and assessing student. ${ }^{7}$ Kamel in his review article titled "Role of faculty development programs" concluded that professional training programs yield favorable outcomes in the teaching and learning practices. ${ }^{6}$ The selfreported perceived confidence level of the participants was significantly increased after teachers training workshops conducted at Chitwan Medical College, Nepal stated by Piryani et $\mathrm{al}^{4}$ and Bilal et $\mathrm{al}^{3}$ in their systematic review and meta-analysis endorses faculty development programs as these promote the teaching, assessment, research, leadership, and administrative skills of medical and allied health professions faculty. ${ }^{3}$

Overall perception of almost all participants except one that training has enormous impact on them academically, professionally and personally. The reaction of some the participants is mentioned here: "training has positive impact, created positive vibe, motivated me to practice what is learnt and made me realize my weak points", "training has enhanced my communication skills and thinking abilities by brainstorming", "it certainly improves my teaching skills and 
helps me in creating healthy class room environment", "it definitely improves my presentation skills, teaching skills and assessment skills and reforms professionally", "I am motivated myself to be good teacher" during this training", and "It has improved my attitude and gave me good confidence while teaching". Only one participant declared that "Not something for myself to work upon" and I have to be more interactive with students, arouse interest in students and more systematic in teaching.

Bilal et al in their systematic review and meta-analysis revealed a significant and positive impact of faculty development program in enhancing faculty's knowledge and professional competence ${ }^{3}$ AlRweithy and Alsaleem revealed in their study "the positive impact of University teaching and learning training program" in enhancing the faculty members' teaching skills. ${ }^{10}$ The findings of study done by Ghazvini et al stated that the faculty development program had a positive impact on participants' abilities. ${ }^{11}$

All participants' faculty committed what's learnt/ acquired during training somehow to apply in practice. Some of their statements are cited here: "manage how to be a good teacher", I transform my teaching "How to make the students understand concept, "use appropriate teaching learning methods", "use scientific way for assessing the students", use MCQs, SAQs, LEQs for assessment, I instill curiosity in students, and I focus more upon "how to teach besides what to teach"

The limitations of this study were small sample size of the participants and assessment of the reaction of the participants and immediate impact of training on the participants. Overall, the reaction of the participants was constructive regarding usefulness, content, relevance and facilitation of training. The participants acknowledged the importance of sessions on curriculum, teaching/learning methods, PBL", micro teaching" and assessment and strongly agreed that this training transformed them as better educator. The content of training course was adequate and delivered systematically, group work exercises were best resources, and resource persons and facilitator were friendly and competent, however, they suggested to reduce the time of training and include more group work. Almost all participants except one perceived that training has immense impact on them academically, professionally and personally. All participants committed what's learnt/acquired will apply in practice.

\section{REFERENCES}

1. Piryani RM, Piryani S, et al. Perception of the faculty participants participated in first Teachers' training workshop conducted at Universal College of Medical Sciences Bhairahawa Nepal. Biomed J Sci \& T. 2019;21(2):15804-7.
2. Fernandez N, Audétat MC. Faculty development program evaluation: a need to embrace complexity. Advances in Medical Education and Practice. 2019;10:191-9.

3. Bilal, Guraya SY, Chen S. The impact and effectiveness of faculty development program in fostering the faculty's knowledge, skills, and professional competence: A systematic review and meta-analysis. Saudi Journal of Biological Sciences. 2019;26:688-97.

4. Piryani RM, Dhungana GP. Piryani S, Neupane M. Evaluation of teachers training workshop at Kirkpatrick level 1 using retro-pre-questionnaire. Advances in Medical Education and Practice. 2018;9:453-7.

5. Agarwal AK. Development of Medical Teacher: A prospective for challenges in India. Int J Educ Psychol Res. 2016;2:141-4.

6. Kamel AM. Role of faculty development programs in improving teaching and learning. Saudi J Oral Sci. 2016;3:61-8.

7. Joshi M, Shrestha I, Bhandary S: Evaluation of core faculty development workshop: experience from Patan Academy of Health Sciences, Nepal. Journal of Patan Academy of Health Sciences. 2016 Dec;3(2):36-40.

8. Dhungana GP, Piryani RM, Chapagain ML, Neupane M. Effectiveness of Teacher Training conducted at Chitwan Medical College, Bharatpur, Nepal. Journal of Chitwan Medical College. 2015;5(12):1-5.

9. Baral N, Nepal AK, Paudel BH, Lamsal M. Effect of Teachers training workshop outcomes on real classroom situations of undergraduate medical students. Kathmandu Univ Med J. 2015;50(2):162-6.

10. AlRweithy E, Alsaleem B. The efficiency of the University teaching and learning training program (UTL) on developing the teaching competencies of the teaching staff at Imam University. Education. 2014;135:9-18.

11. Ghazvini K, Mohammadi A, Jalili M. The Impact of the faculty development workshop on educational research abilities of faculties in Mashhad University of Medical Sciences. Future. Med. Educ. J. 2014;4:24-7. 